\title{
Effect of Community Characteristics and Diseases due to Metabolic Disorders on Heart Disease in Indonesia
}

\author{
Mugeni Sugiharto', Lukman Prayitno', Galih Arianto', Agung Dwi Laksono \\ ${ }^{1}$ Health Researcher, The Center of Research and Development For Humanities and Health Management \\ Ministry of Health, Republic of Indonesia
}

\begin{abstract}
Introduction: Heart disease is still a global health problem and the highest cause of death in Indonesia. This study aims to analyze the influence of demographic factors and metabolic disease on heart disease. Methode: It is quantitative research with cross-sectional design. The data came from the results of the 2018 Basic Health Research survey. Data analysis uses logistic regression. The population was all households in Indonesia. The sample was population aged 15 years. Results: Community characteristics and metabolic disease factors significantly affected the P value of the Wald's test $(\mathrm{Sig})<0.05$. Based on the value of Nagelkerke R Square (Pseudo R-Square), demographic factors have an influence of $3 \%$ and metabolic disease factors have an influence of $6 \%$ on heart disease. Conclusion: Community characteristics and metabolic disease factors have a significant effect on heart disease. Therefore, it is necessary for health workers to socialize government policies regarding guidelines for preventing heart and blood vessel disease correctly and comprehensively.
\end{abstract}

Keywords: Heart, Demography, Metabolic, Indonesia

\section{Introduction}

Non-infective disease control is performed comprehensively, efficiently, and effectively, integrative, and sustainable (1). Heart disease constitutes the highest mortality cause in Indonesia despite government efforts to decrease the morbidity and mortality rate by establishing the National Cardio cerebrovascular Disease Prevention Committee ${ }^{(2)}$. Indonesian Republic Health Ministry has made a particular program to prevent these heart disease risk factors, consisting of primary and secondary preventions. Primary prevention aims to reduce the number of first-time events, and secondary prevention aims to reduce the recurrence of events in patients treated for heart disease ${ }^{(3)}$. Although cases of heart disease can be prevented, there are still many cases in the community because there are still many people who do not know the characteristics of heart disease and the factors that cause it ${ }^{(4)}$.
Mortality due to non-infective disease increases $15 \%$ globally, and heart disease is found most, reaching 81.100 .000 cases in the world. The increased heart disease is due to general lack of understanding about risk factors to cause heart disease ${ }^{(5)(6)}$; in fact, the disease can be prevented by an early detection system and risk factor control, according to the heart disease control manual that has been set by the government ${ }^{(7)}$.

According to Huma, S et al. 2012 in Budiman et al. $2015^{(8)}$, risk factors co cause heart and blood vessel diseases include 1) biological factors such as family history, age, gender, race/ethnic background, and 2) modifiable factors such as hypertension, diabetes mellitus, obesity, smoking, alcohol consumption, physical activity, diet, food and beverage consumption and stress ${ }^{(8),(7)}$. Other causing factors are hereditary, geography, atherosclerosis, peripheral artery disease, stroke, and dyslipidemia ${ }^{(6)}$. 
Metabolic diseases such as hypertension, diabetes mellitus (DM), and stroke belong to deadly diseases other than heart disease and cancer. Stroke ranks third as deadliest disease after heart disease ${ }^{(9)}$. Patients with DM risk 2 to 4 folds to have heart disease $^{(10)}$, and hypertensive persons risk 2.7 folds higher to have heart disease. Today, heart disease is no longer specific to find in elderly aged $>60$ years old but, but now it has attacked under 40 years to 15 years, this is due to modern lifestyle patterns such as consuming fast food ${ }^{(6)(11)(12)}$.

Based on the description above, that heart disease as dadly non-communicable disease. However, it can be prevented by doing control and knowing the risk factor heart disease. Therefore it is crucial problem to conduct a study to analyze the effect of demographic factors and metabolic disease on heart disease in Indonesia. This research aimed to analyze the effect of demographic and metabolic disease on heart disease in Indonesia.

\section{Methode}

\section{Data Source}

The study employed secondary data from the 2018 Indonesian Basic Health Survey. The 2018 Indonesian Basic Health Survey was a cross-sectional survey at the national level.

\section{Variables}

The limitation of analysis and discussion in this study is to only use data on community characteristics such as: age, latest education, and employment. The study also employed metabolic disease (stroke, hypertension, and diabetes mellitus) and heart disease as variables. The dependent variable was heart disease with a nominal scale where code response $1=$ Yes (suffering), and 2 = No. Respondents who suffer a stroke, hypertension, and diabetes mellitus diseases also have a nominal scale (code $1=$ Yes (suffering), code 2 = No (Not Suffering). Gender is coded by $1=$ male and $2=$ female. According to $\mathrm{WHO}$, age category refers to age division where $1=$ elderly aged $\geq 60$ years old and $2=$ non-elderly $(15$ to $<60$ years old). Education was coded by $1=$ higher education (respondents have higher education certificate at least D1 and up to a doctoral degree) and $2=$ senior school schole and under. Workers is coded by $1=$ working in the governmental institution (Civil Servant, Military, Police, State Owned Company) and 2 = private-sector workers.

Definition of heart disease, stroke, hypertension, and diabetes mellitus refers to the 2018 Indonesian Basic Health Survey research guide. Heart disease is defined as all abnormality in heart including coronary heart, heart failure (decompensatio cordis), valve abnormality, heart muscle swelling etc that are diagnosed by general. Stroke is defined as failure in brain characterized by sudden, progressive and fast appearance due to non traumatic impeding blood circulation in brain. Hypertension or high blood pressure is defined as condition where blood pressure in arteries is chronically higher than normal. Diabetes mellitus is defined as metabolic disease with set of symptoms which occur due to increased blood glucose beyond normal value ${ }^{(13)}$.

\section{Data Analysis}

The study analyzed data by binary logistic regression since the dependent, becouse independent variables have a nominal scale, with confident Interval (CI) was 95\%, and significance degree $\alpha 5 \% . \mathrm{H}_{0}$ would be rejected if the variable in the equation table showed $\mathrm{p}$ - value of wald test $(\mathrm{Sig})<0.05$, indicating that each independent variables has significant effect on Y (dependent). The effect rate was shown by EXP $\beta$ or odds ratio (OR) and direction of effect is based on Beta Natural Algorithm Analysis ( $\beta$ ) result. 


\section{Ethical Approval}

The 2018 Indonesian Basic Health Survey Ethic has passed the ethical test. The 2018 Indonesian Basic Health Survey Ethic received ethical clearance from the National Institute of Health Research and Development, the Republic of Indonesia's Ministry of Health (No LB.02.01/2/KE.024/2018).

\section{Results}

Total respondents (n) are 193,126,724, who suffer from heart disease due to demographic and metabolic factors as follows :

Table 1. Percentage between healthy individuals and those who suffer heart disease according to community characteristics and metabolic data

\begin{tabular}{|c|c|c|c|}
\hline \multirow{2}{*}{ Variables } & \multicolumn{3}{|c|}{ Heart Disease } \\
\hline & No & Yes & *p-value \\
\hline \multicolumn{4}{|l|}{ Community characteristics } \\
\hline 1. Gender & 98,2 & 1,80 & 0.000 \\
\hline - Male & 49,03 & 0,80 & \\
\hline - Female & 49,17 & 1 & \\
\hline 2. Age group & 98,2 & 1,80 & 0.000 \\
\hline - $\quad 15-59$ & 87,16 & 1,28 & \\
\hline - $\quad \geq 60$ & 11,04 & 0,52 & \\
\hline 3. Education Level & 98,2 & 1,80 & 0.000 \\
\hline - Senior high school and under & 89,73 & 1,62 & \\
\hline - Higher educatioan & 8,47 & 0,18 & \\
\hline 4. Work type & 98,2 & 1,80 & 0.000 \\
\hline - Governmental institution & 95,28 & 1,72 & \\
\hline - $\quad$ Privat sector & 2,92 & 0,08 & \\
\hline - $\quad$ Penyakit Metabolik & No & Yes & \\
\hline 1. Hypertensi & 98.2 & 1.8 & 0.000 \\
\hline - No & 91.0 & 1.3 & \\
\hline - $\quad$ Yes & 7.2 & 0.5 & \\
\hline 2. Diabetes Mellitus & 98.2 & 1.8 & 0.000 \\
\hline - $\quad$ No & 96.3 & 1.6 & \\
\hline - Yes & 1.9 & 0.2 & \\
\hline 3.Stroke & 98.2 & 1.8 & 0.000 \\
\hline - $\quad$ No & 97.2 & 1.7 & \\
\hline - Yes & 1.0 & 0.1 & \\
\hline
\end{tabular}

Note: $\mathrm{n}$ sample are $193,126,724,{ }^{*} \mathrm{p}<\alpha(0.05)$; Confidence Interval (CI) 95\%. 
Based on demographics, the highest heart disease rate is found women have a higher prevalence with $1.00 \%$ where men have $0.80 \%$. Age group $<60$ years old has $1.28 \%$ or higher than age group $\geq 60$ years old with $0.53 \%$, while senior high school and under score $1.62 \%$ or higher than high education graduates with 0.18 and governmental institution have $1.72 \%$ or higher than respondents who work in private sector workers with $0.08 \%$. Heart disease is more common in urban communities, female gender, age $<60$, not graduated from college, government employees. Based on table value of variable in the Equation, respectively show $\mathrm{P}$ value of wald test $(\mathrm{Sig})<0,05$. Nagelkerke R Square value (Pseudo R-Square) 3\%, hence demographic factors have $3 \%$ effect on heart disease incidence.

Analysis in three metabolic diseases suffered by respondents $(n=193,126,724)$ showed $10.9 \%$ from total respondents who suffer illness like hypertension $7.7 \%$, but those who have heart disease $0.5 \%$, diabetes mellitus $2.1 \%$ and those who have heart disease $0.2 \%$, and stroke $1.1 \%$ and those who have heart disease $0.1 \%$, while respondents without these diseases metabolic were $89.1 \%$. Highest metabolic disease to cause heart disease is hypertension with $0.5 \%$ followed by diabetes mellitus of $0.2 \%$ and the lowest is stroke with $0.1 \%$. The percentage of heart disease is greater in respondents with hypertension, diabetes mellitus and stroke. The effect of metabolic disease factors on heart disease, according to the table value of Variables in The Equation, each of which shows the $\mathrm{P}$ value of the Wald test $(\mathrm{Sig})<0.05$. The value of Nagelkerke R Square (Pseudo R-Square) is 6\%, so that demographic factors have a $6 \%$ influence on the occurrence of heart disease.

Analysis result binary logistic regression to total respondents $(n=193,126,724)$ among heart disease patients with the factors that influence both according to demographic factor group and metabolic deseases group, the result as follows :

Table 2. The results of binary logistic regression, between heart disease with the community characteristics and metabolic factors.

\begin{tabular}{|c|c|c|c|c|}
\hline \multirow{3}{*}{ Predictors } & \multicolumn{4}{|c|}{ Heart Disease } \\
\hline & \multirow{2}{*}{ p-value } & \multirow{2}{*}{$\begin{array}{c}\operatorname{Exp}(\beta) \\
(\text { Odd Ratio / OR })\end{array}$} & \multicolumn{2}{|c|}{$95 \% \mathrm{CI}$} \\
\hline & & & $\begin{array}{l}\text { Lower } \\
\text { Bound }\end{array}$ & $\begin{array}{l}\text { Upper } \\
\text { Bound }\end{array}$ \\
\hline Gender (female with male) & 0.000 & 1,221 & 1,218 & 1,224 \\
\hline Age (ages $\geq 60$ years old with $15-59$ years) & 0.000 & 3,353 & 3,345 & 3,361 \\
\hline $\begin{array}{l}\text { Education (higher education with senior high school } \\
\text { and under) }\end{array}$ & 0.000 & 1,140 & 1,136 & 1,145 \\
\hline $\begin{array}{l}\text { Workers type (Governmental institution with privat } \\
\text { sector) }\end{array}$ & 0.000 & 1,607 & 1,598 & 1,616 \\
\hline Betwen hypertension with no hypertension & 0.000 & 3.392 & 3.384 & 3.401 \\
\hline Betwen diabetes Mellitus:with No diabetes Mellitus & 0.000 & 3,103 & 3.091 & 3.115 \\
\hline Betwen stroke with No stroke & 0.000 & 2.044 & 2.033 & 2.054 \\
\hline
\end{tabular}

Note: $\mathrm{n}$ sample are 193,126,724, ${ }^{\star} \mathrm{p}<\alpha(0.05)$; Confidence Interval (CI) 95\%. 
Community characteristics factors according to gender, age, aducation, and work group that shows significant effects $\mathrm{p}<\alpha(0.05)$ with Confidence Interval (CI) 95\%. Gender effect between female and male shows EXP $\beta$ is 1.221 with CI 95\% (1.2181.224), so that female has heart disease risk 1.221 time higher than male. Age factor effect between $\geq$ 60 years old with 15-59 years old shows the result of EXP $\beta=3.353$ and CI 95\% (3.345-3.361), so that $\geq 60$ years old are more at risk of heart disease 3.43 fold higher than 15- 59 years old. Education factor between higher education with senior high school and under has EXP $\beta=1.140$ and CI 95\% (1.136-1.145), so that the individuals with higher education have heart disease risk 1.14 fold higher than senior high school and under background. Workers factor between Governmental institution and privat sector has EXP $\beta$ $=1.607$ and CI 95\% (1.598-1.616), so that working in governmental institution have heart disease risk 1.61 higher than private sector..

Analysis result binary logistic regression to metabolic patients show metabolic disease factor like hypertension, diabetes mellitus and stroke in table Variable in the equation indicates significant effect of wald test result $\mathrm{P}$ value $<0.05$, pada CI $95 \%$ on heart disease. Result of Nagelkerke R Square value in table of Model Summary is $0.06(6 \%)$, hence metabolic disease can explain its effect on heart disease of $6 \%$. Effect of hypertensive individual to have heart disease shows $\operatorname{Exp}(\beta)=3,392$ and CI 95\% (3.384-3.401), and risk to have heart disease is 3.92 folds higher than non hypertensive. Effect of diabetes mellitus patients on heart disease has EXP $\beta=3.103$ and CI of 95\% (3.091-3.115), hence diabetes mellitus (DM) individuals risk 3.103 folds higher than non diabetes mellitus individuals to have heart disease. Effect of stroke individuals shows EXP $\beta=2.044$ and CI 95\% (2.033-2.054), hence have risk to have heart disease 2.044 folds higher than non stroke individuals.

\section{Discussion}

Heart disease, in spite of its lethality and expensive, but heart disease is a type of disease that can be prevented by early detection and control of risk factors ${ }^{(6)}$. Heart disease control in Indonesia is conducted in comprehensive (promotion, preventive, curative and rehabilitative), efficient, effective, integrated and sustainable way ${ }^{(1)}$. Prevention of heart disease in the community can work well, if the community understands the guidelines for controlling heart disease well and applies them correctly ${ }^{(7)}$.

In addition to community characteristics such as gender, age, education and occupation, several previous studies have explained that people who live in urban areas will have a 1.35 times higher risk of heart disease than those who live in rural areas. ${ }^{(14)}$. Heart disease in urban communities is triggered by a lot of pollution, stress, unhealthy behavior, as happened in Nepal, India, which triggers heart disease ${ }^{(15)}$, as well as the urban people's diet which generally contains high fat, high protein, low carbohydrates and low fiber is also a risk trigger. heart disease ${ }^{(16)}$.

Based on age and gender, the binary logistic statistic test indicated a significant effect on heart disease. Women are easier to have heart disease than men, and the age group $>45$ years old is more accessible to have heart disease than those in the lower age group ${ }^{(5)}$. According to age, morbidity and mortality rate due to heart disease increase, and 4 of 5 patients with heart disease aged 65 years old or more were died ${ }^{(17)}$. Overweight is found higher in those at 40 years old age group, and this is the trigger for the high cases of heart disease in that group ${ }^{(15)}$. Another factor states that heart disease is also significantly influenced by gender and duration of diabetes ${ }^{(10)}$. Heart disease is more common in women ${ }^{(5)}$.

The older you are, the more likely it is that rust will stick to the walls, and this is one of the early 
blood flow disorders in the body that can trigger heart disease. Age 20 years old or above, both in men and women who live in American rural areas, show increased mortality due to heart disease, but the difference is found in another region ${ }^{(14)}$.

Education and occupation are part of the demographic factors, which determine a person's socioeconomic status. The higher a person's education, the easier it will be to get a decent job and income, such as a government employee ${ }^{(11)}$. The relationship between the type of work and heart disease shows that work as government employees and retired civil servants has a higher percentage of heart disease than other types of work. Higher income in urban society causes change in diet since in general they often consume fast food with high fat, high protein, low carbohydrate and low fiber. It causes urban society have obesity problem which lead to heart diseasWorking with the government generally earns decent income, if life behavior is not controlled and tends to follow modern behavior such as fast food habits that are high in fat, high in protein, low in carbohydrates and low in fiber. This is one of the reasons why many well-paid employees such as government employees are obese. Obesity is a risk factor for heart disease ${ }^{(16)}$.

Good public knowledge of heart disease shows a significant relationship to heart disease prevention pencegahan $^{(18)}$. Those with low education generally work in the open and due to low knowledge, they also smoke more. Though smoking can trigger stroke and heart disease. Therefore, low education and low employment will be the dominant factors causing heart disease $\mathrm{e}^{(19)(6)}$

Hypertension is a disease caused by persistently increased blood pressure above the normal limit exceeding a systolic blood pressure of less than $140 \mathrm{mmHg}$ and a diastolic blood pressure of less than $90 \mathrm{mmHg}$. The impact of high blood pressure continuously causes damage to the arterial vascular system and hardening occurs due to fatty deposits on the artery walls, thereby narrowing the lumen contained in blood vessels, this is what triggers heart and blood vessel disease ${ }^{(20)}$.

Increased systemic blood pressure due to hypertension can increase resistance on blood pumping from left ventricle adding to heart workload ${ }^{(11)}$.It is in accordance with this research result proving that hypertension has significant effect on heart disease and also in accordance with other result ${ }^{(6)}$. That hypertension constitutes one dominant factor on heart disease case. The high incidence of hypertension and inadequate knowledge about diet and physical activity among urban poor community cause they risk 2-3 folds higher to have heart disease ${ }^{(3)}$.

Diabetes mellitus (DM) in public is known as sweet urine and among practitioners it is known as "The Mother of Diseases", a metabolic disease which lasts in chronic and progressive way characterized by increased blood sugar concentration which lead to more complicated and serious disease and stroke ${ }^{(21)}$. If not treated well, diabetes mellitus will have serious effect to patient and his/her family like role change in family, psychological disturbance, economy problem, change in social habit, productivity and lifestyle ${ }^{(22)}$.

Indonesia ranks fourth as country with most DM patients after United States, China, and India. DM in this research shows 3.1 times higher risk exposing heart disease. It is in accordance with the result of research that DM becomes one disease that can be causing factor for heart disease. DM patients who are not treated comprehensively will lead to be causing factor for heart disease ${ }^{(10)(23)}$.

The metabolic disease of stroke shows as a dominant factor for heart disease. The proportion of stroke is more in those who have heart disease than those without heart disease ${ }^{(6)}$. Stroke remains 
be global health problem since it causes paralysis, permanent neurological damage, become heart disease causing factor and in some countries it ranks second as mortality cause after ischemic heart disease ${ }^{(24)(25)}$.

In Indonesia, stroke case is 12,1 per 1000 (mil) and stroke case rate tend to increase along with increased age both in men and women. From South East Asian Medical Information Centre (SEAMIC) data, it is found that among ASEAN countries, Indonesia ranks highest for stroke patient rate compared with Philipines, Singapore, Brunei, Malaysia, and Thailand. (26)(27)

\section{Conclusion}

Heart disease constitutes non infective disease which causes highest mortality in Indonesia. Risk factor to affect heart disease is community characteristics factors (gender, education and employment) and metabolic diseases (hypertension, diabetes mellitus and stroke). Heart disease and blood vessel diseases in women are higher than in men, individuals at age $\geq 60$ years old risk higher than adult, higher education graduate risk higher than lower education graduate, government employees risk higher than non governmental employees, hypertensive individual risk than non hypertensive, individuals with diabetes mellitus risk higher than non diabetes mellitus individuals and individuals with stroke risk higher than non stroke individuals. Suggestions that can be conveyed are important for healthcare staff to socialize policy of Decree of the Minister of Health of the Republic of Indonesia, No.854/2009 about Heart and Arteries Diseases Control Guide in Indonesia so public is knowledgeable that heart disease is a preventable disease.

\section{Declarations}

\section{Ethics Approval and consent to Participate}

This Manuscript get ethics approval from National
Institute of Health Research and Development, Indonesian Ministry of Health. The ethics permit number was LB.02.01/2/KE.024/2018.

\section{Consent for Publication}

As another health scientific research, enumerator get consent to participate and consent for publication from respondents. Enumerator must read informed consent to the respondents. Before enumerator collect data, respondents must agree by signing in the form of “Approval (Interview) After Explanation".

\section{Availability of Data and Materials}

The datasets used and/or analysed during the current study available from the corresponding author on reasonable request. All data generated or analysed during this study are included in this published article.

\section{Competing Interest}

We do not have any competing interests.

\section{Funding}

Our Institution, Indonesian Ministry of Health, did this research. There are not any funding in making this article.

\section{Author's Contribution}

All the author work together. We have equal contribution. All of us are the main contributors.

\section{Acknowledgement}

Authors would like to thank to the Head of National Intitute Of Health Research and Development, the Head of The Center of Research and Development For Humanities and Health Management of the Indonesian Ministry of Health, the Data Management Team of the National Institute Of Health Research and Development, the Indonesian Ministry of Health. 


\section{References}

1. Ministry of Health of the Republic Indonesia. Regulation of the Minister of Health Number 71 of 2015 Regarding Handling Disease Not_ Infectious.(Penanggulangan Penyakit Tidak Menular). Ministry of Health of the Republic of Indonesia; 2015.

2. Ministry of Health of the Republic Indonesia. Decree of the Minister of Health No. 672 of 2016 Regarding the National Cardiovascular Disease Control Committee (Kepmenkes No 672 Tahun 2016 Tentang Komite Penanggulangan Penyakit Cardiovascular Nasional). Ministry of Health of the Republic of Indonesia; 2016.

3. Indrawati L. Attitude, Perception, Motivation, Family Support And Information Sources Of Patients With Coronary Heart Disease With Risk Factors Secondary Prevention Measures Case Study At Gatot Soebroto Hospital, Jakarta (Hubungan Antara Pengetahuan, Sikap, Persepsi, Motivasi, Dukungan Keluarga Dan Sumber Informasi Pasien Penyakit Jantung Koroner Dengan Tindakan Pencegahan Sekunder Faktor Risiko (Studi Kasus Di Rspad Gatot Soebroto Jakarta). Ilmiah WIDYA Journal. AgustusOktober 2014; Volume 2 Nomor 3:30-6.

4. Kurniasih $\mathrm{S}$ et al. Health Expert System for Diagnosing Heart Disease Web-Based (Sistem Pakar Kesehatan Untuk Mendiagnosa Penyakit Jantung Berbasisweb 4_sri kurniasih). LPKIA Journal ,. Desember 2017;10 No.2.

5. Zahrawardani D, Herlambang Sri K, Anggraheny D. TheAnalysis of Risk Factors of The Case of Coronary Heart Disease at RSUP Dr Kariadi Semarang Muhammadiyah Medical )Analisis Faktor Risiko Kejadian Penyakit Jantung Koroner di RSUP Dr Kariadi Semarang. Kedokteran Muhammadiyah Journal. 2013; Volume 1 No.2:13-20.
6. Ghani L, Susilawati DM, Novriani H. ominant Risk Factors Of Coronary Heart Disease In Indonesia (Faktor Risiko Dominan Penyakit Jantung Koroner di Indonesia). Health Research Bulletin(buletin Penelitian Kesehatan). September 2016;Vol. 44, No. 3,:153-64.

7. Ministry of Health of the Republic Indonesia. Decree of the Minister of Health Number 854 of 2009 Regarding Guidelines for controlling the heart and blood vessels (Kepmenkes 854 tahun 2009. tentang Pedoman pengendalian jantung dan pembuluh darah). 7. Ministry of Health of the Republic of Indonesia; 2009.

8. Budiman, Sihombing R, Pradina R. Correlation of Dyslipidemia, Hypertension and Diabetes Mellitus with Acute Myocardial Infarction (Hubungan Dislipidemia, Hipertensi Dan Diabetes Melitus Dengan Kejadian Infark Miokard Akut). Andalas Public Health Journal(Jurnal Kesehatan Masyarakat Andalas). 2015;10(1):6.

9. Ramadhany FA, Pujarini AL, Candrasari A. Correlation between Diabetes Mellitus and Ischemic Stroke Incidence in RSUD Dr. Moewardi Surakarta Year 2010(Hubungan Diabetes Melitus Dengan Kejadian Stroke Iskemik Di RSUD Dr. Moewardi Surakarta Tahun 2010). Biomedia Journal. Agustus 2013; Vol.5 No.2.

10. Yuliani F, Oenzil F, Iryani D. The Correlation of Various Risk Factors To The Incidence Of Coronary Heart Disease In Patients With Type 2 Diabetes Mellitus (Hubungan Berbagai Faktor Risiko Terhadap Kejadian Penyakit Jantung Koroner Pada Penderita Diabetes Melitus Tipe 2). Andalas Health Journal (Jurnal Kesehatan Andalas). 2014;3(1).

11. Amisi WG, Nelwan JE, Kolibu FK. The Relationship Between Hypertension And The 
Medico-legal Update, January-March 2022, Vol.22, No. 1

Incidence Of Coronary Heart Disease In Patients Treating At Prof. Central General Hospital. Dr. R.D. Kandou Manado (Hubungan Antara Hipertensi Dengan Kejadian Penyakit Jantung Koroner Pada Pasien Yang Berobat Di Rumah Sakit Umum Pusat Prof. Dr. R. D. Kandou Manado). Journal of Public Health (Jurnal Kesehatan Masyarakat),. 2018; Vol 7 No. .4.

12. Zebua R. Bibliometric Analysis and Author Collaboration on Coronary Heart Disease Research Articles in Indonesia 2013 - 2017 Using Online Proquest Database (Analisis Bibliometrika Dan Kolaborasi Pengarang Terhadap Artikel Penelitian Penyakit Jantung Koroner Di Indonesia Tahun 2013 - 2017 Menggunakan Database Online Proquest). Imam Bonjol Journal: Information Science and Library Studies (Jurnal Imam Bonjol: Kajian Ilmu Informasi dan Perpustakaan). September 2018; Vol.2 No.2:72-80.

13. Health Research and Development Agency (Balitbangkes). Guidelines for Filling Out Basic Health Research Questionnaires of 2018 (Pedoman Pengisian Kuesioner Riskesdas 2018). Health Research and Development Agency; 2018.

14. Knudson A, Meit M, Popat S. Rural-Urban Disparities in Heart Disease Policy Brief\#1 from The 2014 Update of the Rural-Urban Chartbook. Rural Health Reform Policy- RESEARCH CENTER; 2014.

15. Sweta B, Radha Devi bangdel. Risk Factors of Cardiovascular Disease between Urban and Rural Adult Population. International Journal of Caring Sciences. Januari 218M;Vol.11.:71-85.

16. Marliyati SA, Simanjuntak M, Kencana DS. Socio-Economic and Body Mass Index (BMI) of Adult Men in Relation to Coronary Heart Disease Risk Factors in Rural and Urban Bogor-
West Java(Sosial Ekonomi Dan Indeks Massa Tubuh (Imt) Pria Dewasa Dalam Kaitannya Dengan Faktor Risiko Penyakit Jantung Koroner Di Perdesaan Dan Perkotaan Bogor-Jawa Barat). Journal of Nutrition and Food (Jurnal Gizi dan Pangan). Maret 2010; Vol.1:15-25.

17. Marleni L, Alhabib A. Risk Factors for Coronary Heart Disease at SITI Khadijah Islamic Hospital Palembang (Faktor Risiko Penyakit Jantung Koroner di RSI SITI Khadijah Palembang). Health Journal (Jurnal Kesehatan). November 2017; Volume VIII, Nomor 3:478-83.

18. Indrawati L, Werdhasari, A, K Yudi A. The Correlation between Food Consumption Habits of the Poor and the Incidence of Hypertension in Indonesia (Hubungan Pola Kebiasaan Konsumsi Makanan Masyarakat Miskin Dengan Kejadian Hipertensi Di Indonesia). Health Research and Development Media (Media Peneliian dan Pengembang Kesehatan). 2009; Volume XIX Nomor 4:174-84.

19. Kurniawati L, Nurrochmah S, Katmawanti S. The Correlation Between Education Level, Employment Status and Income Level with Age of First Marriage of Women in Kotalama Village, Kedung kandang District, Malang City (Hubungan Antara Tingkat Pendidikan, Status Pekerjaan Dan Tingkat Pendapatan Dengan Usia Perkawinan Pertama Wanita Di Kelurahan Kotalama Kecamatan Kedungkandang Kota Malang). Preventia Journal (Jurnal Preventia). Juni 2017;Vol 2 No 1:1-10.

20. Pradono J. Factors Influencing the Occurrence of Hypertension in Urban Areas (Basic Health Research Data Analysis 2007 (Faktor-Faktor Yang Memengaruhi Terjadinya Hipertensi Di Daerah Perkotaan (Analisis Data Riskesdas 2007). Indonesian Journal of Nutrition (Jurnal Gizi Indon). 2010;33(1):59-66. 
21. Gardiarini P, Sudargo T, Pramantara IDP. Association of Diet Quality, Sosio-demography and Family Support and Blood Glucose Control in Type 2 Diabetes Mellitus Patient in Kanujoso Djatiwibowo Hospital, Balikpapan (Kualitas Diet, Sosio-Demografi, Dan Dukungan Keluarga Hubungannya Dengan Pengendalian Gula Darah Pada Penderita Diabetes Melitus Tipe 2 Di Rumah Sakit Kanujoso Djatiwibowo (Rskd), Balikpapan). Indo Nutrition Journal (Gizi Indon). 2017;40(2):89-100.

22. Wahyuni ES, Hermawati. Perceptions of Fulfilling Nutritional Needs in Diabetes Mellitus Patients in Sawah Kuwung Village, Karang Anyar (Persepsi Pemenuhan Kebutuhan Nutrisi Pada Pasien Diabetes Mellitus Di Desa Sawah Kuwung Karang Anyar). Jurnal Care. Tahun 2017; Vol .5, No2,

23. Simatupang $M$, Pandelaki K, Panda AL. Relationship Between Peripheral Arterial Disease and Cardiovascular Risk Factors in Type 2 Diabetes Mellitus Patients (Hubungan Antara Penyakit Arteri Perifer Dengan Faktor Risiko Kardiovaskular Pada Pasien Dm Tipe 2). Jurnal e-CliniC (eCl),. Volume 1, Nomor 1,(Maret 2013,):7-12.
24. Langhorne P, Bernhardt J, Kwakkel G. Stroke Rehabilitation. Lancet Neurol. 14 Mei 2011;Vol 377:1693-702.

25. BOUCHAMA B, NOCHEL JAMES P. Heat Stroke. The New England Journal of Medicine (N Engl J Med,). 20 Juni 2002;Vol. 346, No. 25:1978-88.

26. Setyopranoto I, Bayuangga HF, Panggabean AS, Alifaningdyah S, Lazuardi L, Dewi FST, dkk. Prevalence of Stroke and Associated Risk Factors in Sleman District of Yogyakarta Special Region, Indonesia (Prevalence of Stroke and Associated Risk Factors in Sleman District of Yogyakarta Special Region, Indonesia). Hindawi. 2019; Volume 2019, Article ID 2642458, 8 pages:1-9.

27. Dinata CA, Syafrita Y, Sastri S. Overview of Risk Factors and Types of Stroke in Inpatients at the Internal Medicine Division of the Solok Selatan District Hospital for the Period 1 January 2010 - 31 June 2012 (Gambaran Faktor Risiko dan Tipe Stroke pada Pasien Rawat Inap di Bagian Penyakit Dalam RSUD Kabupaten Solok Selatan Periode 1 Januari 2010 - 31 Juni 2012). Jurnal Kesehatan Andalas. 2013;2(2):57-61. 